\title{
Sistem Informasi Akademik Serta Penentuan Kelas Unggulan dengan Algoritama K-Means di SMP Negeri 3 Ubud
}

\author{
Aniek Suryanti Kusuma* ${ }^{1}$, Komang Sri Aryati ${ }^{2}$ \\ ${ }^{1,2}$ Program Studi Teknik Informatika, STMIK STIKOM Indonesia, Bali \\ e-mail: *1 anieksuryanti@stiki-indonesia.ac.id, ${ }^{2}$ sri.aryati@ stiki-indonesia.ac.id
}

\begin{abstract}
Abstrak
SMP Negeri 3 Ubud adalah instansi pendidikan yang beralamat di Silungan Lotunduh Ubud. Di SMP Negeri 3 Ubud memiliki kelas unggulan, untuk menentukan siswa berhak masuk ke kelas unggulan masih menggunakan sistem manual yaitu menggunakan microsoft excel. Sistem ini tidak efisien karena banyak membutuhkan waktu saat pengerjaanya. Selain itu pengolahan data akademik siswa khususnya data nilai siswa juga masih manual sehingga kesulitan saat membuat laporan. Berdasarkan permasalahan tersebut dibuatkan sebuah Sistem Informasi Akademik serta Penentuan Kelas Unggulan menggunakan metode clustering dengan adanya sistem informasi akademik serta penentuan kelas unggulan terkomputerisasi maka staf administrasi lebih mudah dan cepat dalam mengolah data siswa, data guru dan data pegawai. Metode yang digunakan untuk menentukan kelas unggulan yaitu Clustering dengan algoritma $K$-Means. Dengan algoritma K-Means sistem akan mengolah nilai siswa dan mengelompokkan sesuai dengan nilai terdekat dengan titik pusat cluster. Dengan adanya sistem ini penentuan kelas unggulan lebih cepat dan efisien.
\end{abstract}

Kata kunci-Sistem, Sistem Informasi Akademik, Clustering, K-Means

\begin{abstract}
SMP Negeri 3 Ubud is educational establishments located at Silungan Lotunduh Ubud. SMP Negeri 3 Ubud has excellent class, to define the student entry into superior class using a manual system that is using Microsoft Excel. This system is inefficient because it requires a lot of time when creating. In addition to the data processing of academic, especially a student's scores are still manually so difficult when creating repot. Based on the problems it created an Academic Information System as well as the determination of class excellent using clustering method with K-Means algorithm. with the academic information system and determination superior class computerized then administrative staff easier and faster in processing student data, teacher data and employee data. The method used to determine which class superior that is Clustering K-Means algorithm. With the K-Means algorithm will process the value system and grouping students according to the value closest to the cluster center point. With this system superior class determination more quickly and efficiently
\end{abstract}

Keywords - System, Academic information system, Clustering, K-Means

\section{PENDAHULUAN}

Sesuai dengan Peraturan Menteri Komunikasi dan Informatika Republik Indonesia nomor: 02/PER/M.KOMINFO/1/2010 tentang rencana strategis kementerian komunikasi dan informatika tahun 2010-2014 disebutkan dalam UU No. 17 Tahun 2007 tentang Rencana

Received March 12 $2^{\text {th }}, 2019 ;$ Revised March 20 ${ }^{\text {th }}, 2019 ;$ Accepted March $30^{\text {th }}, 2019$ 
Pembangunan Jangka Panjang Nasional 2005-2025, masyarakat informasi Indonesia diproyeksikan terwujud pada periode ketiga jangka menengah yaitu tahun 2015-2019. Untuk mencapai sasaran tersebut, salah satu persyaratan utama yang harus dipenuhi adalah tersedianya infrastruktur yang memadai dan didukung oleh pengembangan aplikasi, konten, dan industri TIK lokal, hal itu juga didorong dengan berkembangnya kebutuhan manusia dalam kegiatan operasional perusahaan maupun instansi yang mau tidak mau harus melibatkan kecanggihan teknologi, khususnya teknologi komputer dalam melakukan pengolahan data, salah satunya adalah didalam suatu instansi pendidikan, pemerintahan seperti halnya E-Gov [1], dan penentuan keputusan seperti halnya pemilihan E-Commerce Terbaik [2].

SMP Negeri 3 Ubud adalah salah satu instansi pendidikan menengah pertama yang beralamat di Jalan Alas Arum, Silungan Lotunduh Kecamatan Ubud Kabupaten Gianyar. Dari hasil wawancara kepada bapak Drs.I Made Kawi selaku guru dan bagian akademik di SMP Negeri 3 Ubud menyediakan kelas unggulan yaitu kelas A. Kelas A merupakan kumpulan dari siswa yang cerdas memiliki nilai rata-rata yang tinggi. Nilai yang menentukan siswa yang berhak mendapat kelas unggulan yaitu Bahasa Inggris, Matematika, IPA, Bahasa Indonesia, Budi Pekerti dan rata-rata dari nilai rapot. Langkah-langkah menentukan siswa untuk masuk kekelas unggulan yaitu pertama menentukan batas minimal untuk mendapat kelas unggulan, mencari rata-rata masing-masing siswa selanjutnya mebandingkan nilai siswa dengan batas minimal. Jika nilai siswa lebih tinggi dari batas yang ditentukan maka siswa tersebut berhak mendapat kelas unggulan. Sistem yang digunakan masih manual yaitu masih menggunakan microsoft excel. Sistem ini tidak efektif karena guru masih awam dalam menggunakan formula pada microsoft excel sehingga banyak membutuhkan waktu saat membandingkan nilai siswa dengan batas minimal nilai untuk masuk ke kelas A. Selain itu di SMP Negeri 3 Ubud setelah tes akhir semester guru masing-masing mata pelajaran akan menyerahkan nilai hasil belajar siswa ke wali yang bersangkutan untuk di masukan ke rapot siswa dan bagian Akademik diinputkan di program microsoft excel dan pada saat menjelang ujian nasional untuk melengkapi administrasi setiap sekolah harus menyerahkan data nilai rapot dari kelas VII sampai dengan kelas IX semester I masing-masing siswa ke Provinsi. Dalam pengerjaan ini para guru dan bagian akademik juga kesulitan karena harus menyalin kembali nilai siswa supaya berurutan sesui dengan nis dan mata pelajaran. Banyaknya jumlah siswa dan laporan nilai siswa yang dituntut harus benar tanpa ada kekeliruan sangat menyulitkan dan membutuhkan waktu lama saat pengerjaannya. Sering dibutuhkannya informasi secara tiba-tiba berkenaan dengan informasi akademik seperti data kelas, data wali siswa, data absensi dan lainlain penyajiannya belum efektif dan efisien karena belum ada sistem yang secara khusus mengolah data tersebut.

Dari permasalahan tersebut diatas perlu dibuatkan sistem yang terintegrasi dengan data siswa dan nilai siswa berbasis database sehingga saat nilai dibutuhkan sewaktu-waktu membuat laporannya akan lebih efektif dan efisien. Berdasarkan permasalahan tersebut peneliti tertarik untuk membuat penelitian dengan judul "Sistem Informasi Akademik Serta Penentuan Kelas Unggulan Menggunakan Metode Clustering Dengan Algoritma K-Means Di SMP Negeri 3 Ubud". Data processing Akademik merupakan data yang sangat fital bagi sebuah sekolah baik sekolah Swasta maupun Negeri. Dengan adanya Sistem Informasi Akademik serta penentuan kelas unggulan terkomputerisasi maka staf administrasi lebih mudah dan cepat dalam mengolah data siswa, data guru dan data pegawai. Metode yang digunakan untuk menentukan kelas unggulan yaitu clustering dengan algoritma $K$-Means. Dengan algoritma $K$-Means sistem akan mengolah nilai siswa dan mengelompokkan sesui dengan nilai terdekat dengan titik pusat cluster. Peneliti menggunakan metode clustering $K$-means karena algoritma ini merupakan algoritma yang memiliki ketelitian yang cukup tinggi terhadap ukuran objek, sehingga algoritma ini relatif lebih terukur dan efisien untuk pengolahan objek dalam jumlah besar [3].

Dengan adanya sistem ini diharapkan permasalahan yang sering terjadi dalam kegiatan operasional di SMP Negeri 3 Ubud bisa diatasi baik itu pengolahan data siswa, guru, pegawai maupun nilai siswa dan menentukan siswa yang berhak mendapat kelas unggulan lebih cepat, efektif dan efisien.

JSIKTI Vol. 1, No. 3, March 2019 : 143-152 


\section{METODE PENELITIAN}

\subsection{Sistem}

Sistem adalah sebuah tatanan yang terdiri atas sejumlah komponen fungsional (dengan tugas atau fungsi khusus) yang saling berhubungan dan secara bersama-sama bertujuan untuk memenuhi suatu proses/pekerjaan tertentu. Sebagai contoh, system kendaraan terdiri dari : komponen starter, komponen pengapian, komponen penggerak, komponen pengerem, komponen kelistrikan-speedometer, lampu dan lain-lain. Komponen-komponen tersebut diatas memiliki tujuan yang sama, yaitu membuat kendaraan tersebut bisa dikendarai dengan nyaman dan aman. Contoh lain yaitu system perguruan tinggi, yang terdiri dari dosen, mahasiswa, kurikulum, dan lain-lain. Sistem ini bertujuan untuk menghasilkan mahasiswa-mahasiswa yang memiliki kemampuan di bidang ilmunya [4].

Sistem adalah sekumpulan elemen yang saling terkait atau terpadu yang dimaksudkan untuk mencapai suatu tujuan. Sebagai gambaran, jika dalam sebuah sistem terdapat elem yang tidak memberikan manfaat dalam mencapai tujuan yang sama maka elemen tersebut dapat dipastikan bukanlah bagian dari sistem [5].

\subsection{Informasi}

Informasi merupakan hasil olahan data, dimana data tersebut sudah diproses dan diinterpretasikan menjadi sesuatu yang bermakna untuk mengambil keputusan. Informasi juga diartikan sebagai himpunan dari data yang relevan dengan satu atau beberapa orang dalam sesuatu waktu. Suatu informasi berguna bagi pembuat keputusan karena informasi bisa menurunkan ketidak pastian (meningkatkan pengetahuan) tentang hal yang sedang dipikirkan. Makna dari sebuah informasi tentu berbeda-beda antara seorang dengan yang lainnya, tergantung pada tingkat kepentingannya. Kegunaan informasi bagi seseorang sangat tergantung pada waktu. Maksud dari pemrosesan data menjadi informasi simbol-simbol, seperti angka dan abjad dengan tujuan meningkatkan kegunaannya. Suatu sistem yang mentransfer data menjadi sebuah informasi adalah sistem informasi [4].

\subsection{Sistem Informasi Manajemen}

Menurut Murdick dalam Prasojo dan Prasetyo [6] sistem informasi manajemen adalah suatu kelompok orang, seperangkata pedoman, dan petunjuk peralatan pengolahan data, memilih, menyimpan, mengolah dan mengambil kembali data untuk mengurangi ketidakpastian pada pengambilan keputusan dengan menghasilkan informasi untuk manajer pada waktu mereka dapat menggunakannya dengan paling efisian.

Machmud [7] sistem informasi manajemen merupakan suatu sistem yang dapat membantu manajemen di dalam pengumpulan data, pengolahan serta analis evaluasi data dan menyajikan ke dalam batas informasi yang bernilai dan akhirnya sampai pada pengambilan keputusan dimana informasi ini berguna untuk mendukung fungsi operasi manajemen.

\section{4 Sistem Informasi Akademik}

Menurut Yunita, dkk [8] dalam penelitiannya yang berjudul "Sistem Informasi Akademik pada SMA Yanitas Palembang" menyatakan Sistem Informasi Akademik adalah suatu sistem yang dirancang untuk keperluan pengeloaan data-data akademik dengan penerapan teknologi komputer baik hardware maupun softwareyang bertujuan memberikan informasi terhadap para siswa, orang tua siswa dan masyarakat tentang sekolah, fasilitas sekolah, data siswa, absensi siswa, data prestasi siswa, data nilai siswa, dan pembayaran sekolah, jadwal guru piket, dan saran.

\section{2. $5 \mathrm{~K}$-Means}

K-Means merupakan salah satu metode data clustering non hirarkiyang berusaha mempartisi data yang ada ke dalam bentuk satu atau lebih cluster/kelompok. Metode ini 
mempartisi data ke dalam cluster/kelompok sehingga data yang memiliki karakteristik yang sama dikelompokkan ke dalam satu cluster yang sama dan data yang mempunyai karakteristik yang berbeda dikelompokkan ke dalam kelompok yang lain. Adapun tujuan dari data clustering ini adalah untuk meminimalisasikan objective function yang diset dalam proses clustering, yang pada umumnya berusaha meminimalisasikan variasi di dalam suatu cluster dan memaksimalisasikan variasi antar cluster.[9]

Salah satu metode clustering yang paling dasar, yaitu K-Means Clustering. Means berarti nilai rata-rata dari suatu grup data (cluster) [10]. K-Means adalah suatu metode penganalisaan data. Metode $K$-Means berusaha mengelompokkan data yang ada ke dalam beberapa kelompok, dimana data dalam satu kelompok mempunyai karakteristik yang sama satu sama lainnya dan mempunyai karakteristik yang berbeda dengan data yang ada di dalam kelompok yang lain. Dengan kata lain, metode ini berusaha untuk meminimalkan variasi antar data yang ada di dalam suatu cluster dan memaksimalkan variasi dengan data yang ada di cluster lainnya.William membagi algoritma clustering ke dalam kelompok besar seperti berikut :

1. Partitioning algorithms: algoritma dalam kelompok ini membentuk bermacam partisi dan kemudian mengevaluasinya dengan berdasarkan beberapa kriteria.

2. Hierarchy algorithms: pembentukan dekomposisi hirarki dari sekumpulan datamenggunakan beberapa kriteria.

3. Density-based: pembentukan cluster berdasarkan pada koneksi dan fungsi densitas.

4. Grid-based: pembentukan cluster berdasarkan pada struktur multiple level granularity

5. Model-based: sebuah model dianggap sebagai hipotesa untuk masing-masing cluster dan model yang baik dipilih diantara model hipotesa tersebut.

Menurut Santosa dalam Ong [11] Pada dasarnya clustering merupakan suatu metode untuk mencari dan mengelompokkan data yang memiliki kemiripan karakteriktik (similarity) antara satu data dengan data yang lain. Clustering merupakan salah satu metode data mining yang bersifat tanpa arahan (unsupervised) [12-14], maksudnya metode ini diterapkan tanpa adanya latihan (taining) dan tanpa ada guru (teacher) serta tidak memerlukan target output. Dalam data mining ada dua jenis metode clustering yang digunakan dalam pengelompokan data, yaitu hierarchical clustering dan non-hierarchical clustering [15].

Algoritma K-Means pertama kali digagas oleh Macqueen [4]. Langkah-langkah pada algoritma adalah sebagai berikut.

1. Langkah pertama: Tanyakan kepada pemakai algoritma $k$ means, catatan catatan yang akan dibuat menjadi berapa kelompok, sebutlah sebanyaknya $K$ kelompok.

2. Langkah kedua: Secara sembarang, pilihlah $k$ buah catatan (dari sekian catatan yang ada) sebagai pusat-pusat kelompok awal.

3. Langkah ketiga: untuk setiap catatan, tentukan pusat kelompok terdekatnya dan tetapkan catatan tersebut sebagai agota dari kelompok yang terdekat pusat kelompoknya. Hitung rasio antara besaran between cluster variation dengan within cluster variation, lalu bandingkan rasio tersebut dengan rasio sebelumnya (bila sudah ada). Jika rasio tersebut membesar, lanjutkan kelangkah ke empat. Jika tidak hentikan prosesnya.

4. Langkah keempat: perbarui pusat-pusat kelompok( berdasarkan kelompok yang didapat dari langkah ke tiga) dan kembalilah ke langkah ke tiga.

Ediyanto, dkk [3] rumus untuk menghitung centroid cluster ke-i sebagai berikut:

$$
v=\frac{\sum_{i=1}^{n} x_{i}}{n} \quad ; \mathrm{i}=1,2,3, \ldots n
$$

JSIKTI Vol. 1, No. 3, March 2019: 143-152 
Dimana $v$ : centroid pada cluster

$x i$ : objek ke-i

$n$ : banyaknya objek atau jumlah objek yag menjadi cluster.

Sedangkan rumus untuk menghitung jarak antara objek dengan centroid digunakan rumus Euclidian Distance

$$
\mathrm{d}(\mathrm{x}, \mathrm{y})=\|\mathrm{x}-\mathrm{y}\|=\sqrt{\sum_{i-l}^{n}\left(x_{i}-y_{i}\right)^{2}} ;=1,2,3, \ldots, n
$$

dimana $x_{i}$ : objek $x$ ke $-i$

$y_{i}$ : daya $y k e-i$

$n$ : banyaknya objek

\subsection{Perhitungan Metode K-Means}

Untuk mendapatkan hasil penentuan kelas unggulan dengan metode $K$-Means digunakan data nilai raport kelas VII semester 1 disesuaikan dengan parameter nilai yang digunakan untuk memnentukan kelas unggulan tersebut. Dalam raport siswa kurikulum 2013 nilai ada dua masing-masing pelajaran maka dari itu pertama harus menjumlahkan nilai pengetahuan dan ketrampilan dari masing - masing pelajaran pada raport siswa dan didapatkan nilai seperti Tabel 1.

Tabel 1 Data Awal

\begin{tabular}{|l|l|r|r|r|r|r|r|}
\hline $\begin{array}{c}\text { Siswa } \\
\text { ke- }\end{array}$ & Nama siswa & $\begin{array}{c}\text { Agama } \\
\text { \& } \\
\text { Budi } \\
\text { pekerti }\end{array}$ & $\begin{array}{c}\text { Bahasa } \\
\text { Indones } \\
\text { ia }\end{array}$ & $\begin{array}{c}\text { Matem } \\
\text { atiaka }\end{array}$ & IPA & $\begin{array}{c}\text { Bahasa } \\
\text { Inggris }\end{array}$ & Rata-Rata \\
\hline 1 & kadek yudiarta & 6.029 & 6.237 & 6.051 & 6.375 & 6.029 & 6.219818 \\
\hline 2 & $\begin{array}{l}\text { Ikadek adi } \\
\text { agustin }\end{array}$ & 7.04 & 6.159 & 6.154 & 6.741 & 6.014 & 6.352636 \\
\hline 3 & $\begin{array}{l}\text { i made adi } \\
\text { surya widana }\end{array}$ & 7.1 & 6.24 & 6.197 & 6.716 & 6.027 & 6.383273 \\
\hline 4 & $\begin{array}{l}\text { i made agus } \\
\text { arya sutrisna }\end{array}$ & 7.093 & 6.33 & 6.163 & 6.28 & 6.025 & 6.316727 \\
\hline 5 & $\begin{array}{l}\text { i wayan angga } \\
\text { apriana }\end{array}$ & 6.034 & 6.172 & 6.163 & 6.28 & 6.034 & 6.141727 \\
\hline 6 & $\begin{array}{l}\text { i putu angga } \\
\text { junika putra }\end{array}$ & 7.449 & 6.243 & 6.239 & 6.28 & 6.041 & 6.494909 \\
\hline 7 & $\begin{array}{l}\text { Anjas mara } \\
\text { Rudianto }\end{array}$ & 6.82 & 6.164 & 6.23 & 6.181 & 6.012 & 6.220545 \\
\hline 8 & $\begin{array}{l}\text { Dewa Made Ari } \\
\text { Wira Sanjaya }\end{array}$ & 7.055 & 6.285 & 6.23 & 6.36 & 6.237 & 6.304455 \\
\hline 9 & $\begin{array}{l}\text { ni komang Aris } \\
\text { sya Dewi }\end{array}$ & 7.195 & 6.313 & 6.181 & 6.324 & 6.125 & 6.293818 \\
\hline 10 & $\begin{array}{l}\text { Imade } \\
\text { Darmayasa }\end{array}$ & 6.949 & 6.087 & 6.201 & 6.194 & 6.016 & 6.219909 \\
\hline
\end{tabular}

Pada Algoritma $\mathrm{K}$-Means, langkah-langkah yang dilakukan adalah sebagai berikut:

1. Menentukan banyak cluster.

Langkah pertama adalah menentukan jumlah cluster. Disini akan ditentukan 3 jumlah

cluster yaitu cluster $C 1$ untuk kelas A, cluster C2 untuk kelas B, cluster C3 sebagai kelas C.

2. Menentukan titik pusat cluster.

Dalam menentukan kelas unggulan ini digunakan beberapa parameter nilai pelajaran sebagai penentu untuk mendapatkan kelas unggulan yaitu: pendidikan agama dan budi pekerti, Bahasa Indonesia, Matematika, IPA, Bahas inggris dan rata-rata nilai rapot berdasarkan parameter tersebut diberikan titik cluster untuk kelas A yaitu $\mathrm{C}_{1}(7.2 ; 6.46 ; 6.47 ; 6.7 ; 6.71 ; 6.74)$ yang artinya pendidikan agama dan budipekerti $=7.2$, Bahasa Indonesia $=6.46$, Matematika $=6.47, \mathrm{IPA}=6.7$, Bahasa inggris $=6.71$, rata-rata 
raport $=6.74$. Cluster untuk kelas $\mathrm{B}$ yaitu $\mathrm{C}_{2}=(6.9 ; 6.33 ; 6.23 ; 6.3 ; 6.22 ; 6.44)$. Cluster untuk kelas $\mathrm{C}$ yaitu $\mathrm{C}_{3}=(6.2 ; 6.1 ; 5.9 ; 6 ; 6.02 ; 6.14)$

3. Menghitung jarak obyek ke centroid dengan menggunakan rumus jarak euclidean dengan rumus sebagai berikut:

$$
D=(i, j) \sqrt{\left(x_{1 i-} x_{1 j}\right)^{2}}+\left(x_{2 i-} x_{2 j}\right)^{2}+\ldots+\left(x_{k i-} x_{k j}\right)^{2}
$$

Dimana:

$\mathrm{D}(\mathrm{i}, \mathrm{j})=$ jarak data ke $\mathrm{i}$ pusat cluster $\mathrm{j}$

$X_{k i}=$ Data ke $i$ pada atribut data ke $k$

$X_{k j} \quad=$ Titik pusat ke $J$ pada atribut ke $K$

Perhitungan jarak siswa pertama dengan pusat cluster pertama adalah:

$$
d_{11}=\sqrt{\begin{array}{c}
(6.029-7.2)^{2}+(6.237-6.46)^{2}+(6.051-6.47)^{2}+(6.375-6.7)^{2}+ \\
(6.029-6.71)^{2}+(6.2198181-6.74)^{2}=1.560931172
\end{array}}
$$

Perhitungan jarak siswa pertama dengan pusat cluster kedua adalah:

$$
d_{12}=\sqrt{\begin{array}{c}
(6.029-6.9)^{2}+(6.237-6.33)^{2}+(6.051-6.23)^{2}+(6.375-6.3)^{2}+ \\
(6.029-6.22)^{2}+(6.2198181-6.44)^{2}=0.943354
\end{array}}
$$

Perhitungan jarak siswa pertama dengan pusat cluster ketiga adalah:

$$
d_{13}=\sqrt{\begin{array}{c}
(6.029-6.2)^{2}+(6.237-6.1)^{2}+(6.051-5.9)^{2}+(6.375-6.0)^{2}+ \\
(6.029-6.02)^{2}+(6.2198181-6.14)^{2}=0.466785
\end{array}}
$$

Perhitungan jarak siswa kedua dengan pusat cluster pertama adalah:

$$
d_{21}=\sqrt{\begin{array}{c}
(7.04-7.2)^{2}+(6.159-6.46)^{2}+(6.154-6.47)^{2}+(6.741-6.7)^{2}+ \\
(6.014-6.71)^{2}+(6.352636-6.74)^{2}=0.923149277
\end{array}}
$$

Perhitungan jarak siswa kedua dengan pusat cluster kedua adalah:

$$
d_{22}=\sqrt{\begin{array}{c}
(7.04-6.9)^{2}+(6.159-6.33)^{2}+(6.154-6.23)^{2}+(6.741-6.3)^{2}+ \\
(6.014-6.22)^{2}+(6.352636-6.44)^{2}=0.546961
\end{array}}
$$

Perhitungan jarak siswa kedua dengan pusat cluster ketiga adalah:

$$
d_{23}=\sqrt{\begin{array}{c}
(7.04-6.2)^{2}+(6.159-6.1)^{2}+(6.154-5.9)^{2}+(6.741-6)^{2}+ \\
(6.014-6.02)^{2}+(6.352636-6.14)^{2}=1.169585
\end{array}}
$$

Perhitungan yang sama dilakukan untuk data ketiga hingga ke tujuh puluh. Hasil perhitungan jarak siswa dengan ketiga pusat cluster dapat dilihat pada Tabel 2. 
Tabel 2 Jarak Setiap Data Siswa Pada Iterasi Yang Ke-1

\begin{tabular}{|l|c|c|c|}
\hline $\begin{array}{l}\text { SISWA } \\
\text { KE- }\end{array}$ & c1 & c2 & c3 \\
\hline 1 & 1.560931172 & 0.943354 & 0.466785 \\
\hline 2 & 0.923149277 & 0.546961 & 1.169585 \\
\hline 3 & 0.852600931 & 0.512554 & 1.220531 \\
\hline 4 & 0.973335914 & 0.308803 & 1.014483 \\
\hline 5 & 1.58998593 & 0.950459 & 0.424862 \\
\hline 6 & 0.920044322 & 0.586947 & 1.378467 \\
\hline 7 & 1.147176545 & 0.373552 & 0.732604 \\
\hline 8 & 0.798923553 & 0.219799 & 1.038212 \\
\hline 9 & 0.887600256 & 0.347398 & 1.119829 \\
\hline 10 & 1.132544725 & 0.404454 & 0.834151 \\
\hline
\end{tabular}

4. Melakukan clustering obyek dengan memasukkan setiap obyek ke dalam cluster (grup) berdasarkan jarak minimumnya. Jarak minimum ditandai dengan blok abu-abu pada tabel diatas. Suatu data akan menjadi anggota dari suatu cluster $\left(\mathrm{C}_{11}, \mathrm{C}_{12}, \mathrm{C}_{13}\right)$ yang memiliki jarak terkecil dari pusat, seperti pada Tabel 3.

Tabel 3 Posisi Cluster Setiap Siswa Pada Iterasi Yang Ke-1

\begin{tabular}{|l|l|}
\hline $\begin{array}{l}\text { Siswa } \\
\text { ke- }\end{array}$ & $\begin{array}{l}\text { Kelompok } \\
\text { Cluster }\end{array}$ \\
\hline 1 & $\mathrm{C} 3$ \\
\hline 2 & $\mathrm{C} 2$ \\
\hline 3 & $\mathrm{C} 2$ \\
\hline 4 & $\mathrm{C} 2$ \\
\hline 5 & $\mathrm{C} 3$ \\
\hline 6 & $\mathrm{C} 2$ \\
\hline 7 & $\mathrm{C} 2$ \\
\hline 8 & $\mathrm{C} 2$ \\
\hline 9 & $\mathrm{C} 2$ \\
\hline 10 & $\mathrm{C} 2$ \\
\hline
\end{tabular}

Dari Tabel 3 dihitung rasio antara besaran between cluster variation (BCV)

$$
\begin{aligned}
& \left.\mathrm{d}\left(m_{1}, m_{2}\right)=\sqrt{(7.2-6.9)}^{2}+(6.46-6.33)^{2}+(6.47-6.23)^{2}+6.7-6.3\right)^{2}+ \\
& (6.71-6.22)^{2}\left(+(6.74-6.44)^{2}=0.80907\right. \\
& \mathrm{d}\left(m_{1}, m_{3}\right)=\sqrt{(7.2-6.2)^{2}}+(6.46-6.1)^{2}+(6.47-5.9)^{2}+(6.7-6)^{2}+ \\
& (6.71-6.02)^{2}+(6.74-6.14)^{2}=1.667513 \\
& \mathrm{~d}\left(m_{2}, m_{3}\right)=\sqrt{(6.9-6.2)^{2}}+(6.33-6.1)^{2}+(6.23-5.9)^{2}+(6.3-6)^{2}+(6.2- \\
& 6.02)^{2}+(6.44-6.14)^{2}=0.933702 \\
& \mathrm{BCV}=\mathrm{d}\left(m_{1}, m_{2}\right)+\mathrm{d}\left(m_{1}, m_{3}\right)+\mathrm{d}\left(m_{2}, m_{3}\right)=0.80907+1.667513+0.80907= \\
& 3.410289
\end{aligned}
$$




\section{HASIL DAN PEMBAHASAN}

Implementasi program yaitu menggunakan bahasa pemrograman visual basic. Net dimana SQL Server sebagai databasenya. Algoritma K-Means sistem akan mengolah nilai siswa dan mengelompokkan sesui dengan nilai terdekat dengan titik pusat cluster.

\subsection{Menu Utama}

Gambar 1 menunjukkan menu utama user dapat melakukan beberapa proses yang ada pada sistem, proses tersebut antara lain memproses data pengguna, memproses data siswa, memproses data pegawai, memproses data guru, memproses data kelas, memproses data wali kelas, memproses data jenjang siswa, memproses data ekstra, memproses nilai siswa, memproses data pelajaran, memproses data kepala sekolah, memproses absensi siswa, memproses data siswa untuk mendapatkan kelas unggulan dan menampilkan laporan akademik siswa seperti nilai rapot, data pribadi siswa dan data guru.

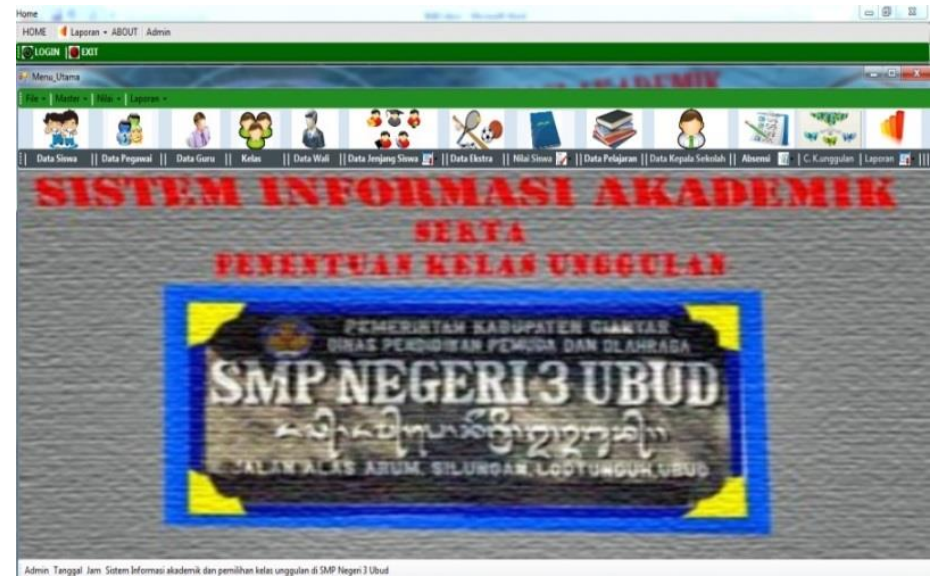

Gambar 1 Tampilan Menu Utama

\subsection{Form Mengolah Data Pengguna}

Saat tombol pengguna dipilih pada menu file maka menampilkan form untuk memproses data pengguna. Pada form pengguna ini user tidak dibolehkan untuk mengetik kode pengguna dan nama pengguna secara langsung melainkan harus melalui tombol cari data pegawai jika pengguna berstatus pegawai dan cari data guru jika pengguna berstatus guru. Untuk nama login dan password bisa ketik sesui dengan ke inginan user. Pada lavel pengguna bisa memilih pada combobox untuk mencari lavel pengguna. Tombol cari pada lavel pengguna akan menampilkan form level pengguna, pada form level user bisa menambahkan data level pengguna. Pada form pengguna user bisa melakukan pengolahan pada tabel dbpengguna yaitu tambah (insert), ubah (update), hapus (delete). Untuk pencarian user bisa menekan tombol record pengguna maka akan tampil form rcord pengguna, untuk mencari data pengguna user bisa memasukkan nama pengguna yang ingin dicari pada kolom cari. Setelah itu maka akan di tampilkan beberapa nama yang dimaksudkan untuk memilih user bisa double click pada nama yang dipilih.

\subsection{Form Mengolah Data Siswa}

Gambar 2 menunjukkan ketika menu data siswa dipilih maka form untuk mengolah data siswa akan tampil. Pada form ini, user dapat melakukan pengolahan pada dbsiswa yaitu tambah (insert) dan Ubah (Update) data siswa sedangkan untuk mencari data siswa bisa dengan memilih tombol record siswa yang ada di kanan bawah, maka akan tampil form record data siswa. Untuk melakukan pencarian bisa memasukkan Nis siswa yang akan dicari pada kolom cari pada form record data siswa. Untuk menambah data siswa user bisa menginputkan nis, nama siswa, tempat/tanggal lahir, jenis kelamin, alamat, nama ayah, nama ibu, kerja ayah, kerja ibu ke delam kolom yang disediakan, setelah data lengkap user bisa menekan tombol simpan 
maka data akan tersimpan dalam database dbsiswa. Jika data belum lengkap atau kolom ada yang kosong maka sistem akan mengeluarkan peringatan pesan untuk mengecek data lagi.

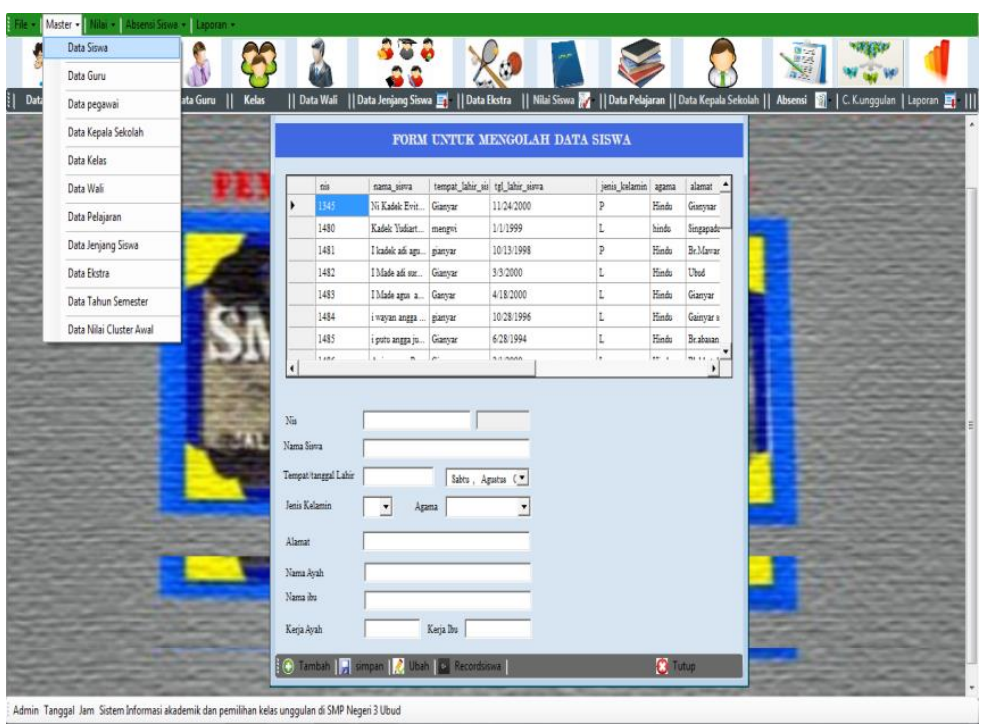

Gambar 2 Tampil Form Data Siswa

\subsection{Pengujian Metode}

Dalam Pengujian metode menurut Raharjo [16] menggunakan yang pertama yaitu Precision adalah tingkat ketepatan antara informasi yang diminta oleh pengguna dengan jawaban yang diberikan oleh sistem. Hasil dari precision adalah sebagai berikut:

$$
\begin{gathered}
\text { Precision }=\frac{\text { jumlah } \text { kelas } A \text { sesuai dengan hasil dilapangan }}{\text { jumlah kelas A yang didapat dari sistem }} \\
\text { Precision }=\frac{26}{31}=0.83=83 \%
\end{gathered}
$$

Kedua menggunakan Accuracy yaitu didefinisikan sebagai tingkat kedekatan antara nilai prediksi dengan nilai aktual. Hasil dari accuracy adalah sebagai berikut:

Accuracy $=\frac{(\text { jumlah kelas } A \text { sesuai dengan hasil dilapangan }+ \text { jumlah bukan kelas } A)}{\text { Total jumlah siswa }}$

$$
\text { Accuracy }=\frac{(26+33)}{64}=0.92=92 \%
$$

\section{KESIMPULAN}

Berdasarkan pembahasan sistem informasi akademik serta penentuan kelas unggulan dengan algoritma $K$-Means yang telah dijelaskan sebelumnya adapun simpulan dari laporan ini yaitu tahapan merancang dan membangun sistem informasi akademik adalah yang pertama wawancara yang dilakukan kepada bapak Drs. I Made Kawi selaku bagian akademik kedua analisis sistem dimana pada tahap ini dianalisa kebutuhan dari sistem yang akan dibangun supaya bisa mengatasi permasalahan yang terjadi ketiga menentukan metode yaitu menggunakan metode $K$-Means. Dengan algoritma $K$-Means sistem akan mengolah nilai siswa dan mengelompokkan sesui dengan nilai terdekat dengan titik pusat cluster. Pada tahap 
selanjutnya dilakukan perancangan sistem yaitu menggunakan teknik terstruktur yaitu menggunakan data flow diagram. Implementasi program yaitu menggunakan bahasa pemrograman visual basic.Net dimana SQL Server sebagai databasenya. Berdasarkan pengujian metode menggunakan precision didapatkan hasil yaitu $83 \%$ dan kedua menggunakan tingkat accuracy didapatkan hasil yaitu $92 \%$ dari hasil disebut metode $K$-means cukup efektif digunakan untuk menentukan siswa yang berhak masuk ke kelas unggulan.

\section{DAFTAR PUSTAKA}

[1] P.Sugiartawan,I.D.K.R. Rustina, R.W.S. Insani, "E-Government Media Informasi Alat Kelengkapan Dewan Provinsi Bali dan Media Diskusi Berbasis Website," J. Sist. Inf. dan Komput. Terap. Indones., vol. 2, no. 1, 2018.

[2] I. Pratistha, P. Sugiartawan, U. G. Mada, M. Manajemen, and U. G. Mada, "Sistem Pendukung Keputusan Kelompok Pemilihan E-Commerrce Menggunakan Metode Profile Matching dan BORDA," vol. 1, no. 1, 2018.

[3] Ediyanto; Mara, Muhlasah N, dan Satyahadewi, Neva, "Pengklasifikasian Karakteristik Dengan Metode K-Means Cluster Analysis", Buletin Ilmiah Mat. Stat. dan Terapannya (Bimaster) Vol. 2, No 2, 133-136, 2013.

[4] Macqueen, J. B, "Some Methods for Classification and Analysis of Multivariate Observations, Proceedings of 5-th BerkeleySymposium on Mathematical Statistics and Probability," Berkeley: University of Califonia Press, 1967.

[5] Kusrini, "Konsep dan Aplikasi Sistem Pendukung Keputusan," Yogyakarta: Andi, 2007.

[6] Prasojo, Lantip D dan Prasetyo, Eko B, "Sistem Informasi Manajemen Dalam Pembelajaran," Makalah Ilmiah Pembelajaran Vol.1, No. 2, ISSN 0216-7999, 2005.

[7] Machmud, Rizan, "Hubungan Sistem informasi Manajemen dan Pelayanan dengan kinerja Pegawai Pada Rutan Denpasar," Jurnal Capacity STIE AMKOP Makassar ISSN : 1907-3313, 2013.

[8] Yunita, Renia; Widana, Arya dan Irfani, M. Haviz, "Sistem Informasi Akademik Pada SMA Yanitas Palembang,” STIMIK GI MDP, 2004.

[9] Kridalukmana, Rinta, "Dasar Komputer dan Pemrograman .Universitas Diponegoro.Fakultas Teknik Universitas Diponegoro, 2009.

[10] Syafrianto, Andri, "Perancangan Aplikasi K-Means Untuk Pengelompokan Mahasiswa STMIK ELRAHMA Yogyakarta Berdasarkan Frekuensi Kunjungan Ke Perpustakaan Dan IPK, Yogyakarta: STIMIK ELRAHMA, 2009.

[11] Ong, Johan Oscar, "Implementasi Algoritma K-Means Clusttering Untuk Menentukan Strategi Marketing President University," Jurnal Ilmiah Teknik Industri Vol. 12, ISSN 1412-6869, 2013.

[12] I. P. A. H. Krisnawan, T. Sutanto, and E. Sutomo, "Menggunakan Metode K-Means untuk Promosi Paket Wisata," STIKOM Surabaya, 2013.

[13] Asroni and R. Adrian, "Penerapan Metode K-Means Untuk Clustering Mahasiswa Berdasarkan Nilai Akademik Dengan Weka Interface Studi Kasus Pada Jurusan Teknik Informatika UMM Magelang," Ilm. Semesta Tek., vol. 18, no. 1, pp. 76-82, 2015.

[14] A. Bastian, H. Sujadi, and G. Febrianto, "Penerapan Algoritma K-Means Clustering Analysis Pada Penyakit Menular Manusia (Studi Kasus Kabupaten Majalengka)," J. Sist. Inf. (Journal Inf. Syst., vol. 14, no. 1, pp. 26-32, 2018

[15] F. L. Sibuea and A. Sapta, "Pemetaan Siswa Berprestasi Menggunakan Metode K-Means Clustering," J. Teknol. dan Sist. Inf., vol. IV, no. 1, pp. 85-92, 2017.

[16] Raharjo, Beni, "Nature, Environment, Remote Sensing, GIS, IT and Myself," 2013. 